\title{
Response of $\mathrm{C}_{3}$ and $\mathrm{C}_{4}$ grasses to supplemental summer precipitation
}

\author{
R. HOWARD SKINNER, JON D. HANSON, GORDON L. HUTCHINSON, AND GERALD E. SCHUMAN
}

Authors are Plant Physiologist, USDA-ARS, Pasture Systems and Watershed Management Research Unit, Building 3702 Curtin Road, University Park, Penn. 16802, Rangeland Scientist and research leader, USDA-ARS, Northern Great Plains Research Laboratory, Highway 6 South, Mandan, N.D. 58554, Soil Scientist, USDA-ARS, Soil-Plant-Nutrient Research Unit, 301 S. Howes, Fort Collins, Colo. 80522 and Soil Scientist, USDA-ARS Rangeland Resource Research Unit, 8408 Hildreth Rd. Cheyenne, Wyo. 82009. At the time of research, RHS and JDH were Plant Physiologist and Rangeland Scientist, USDA-ARS, Great Plains Systems Research Unit, Fort Collins, Colo. 80522.

\section{Abstract}

Rangeland plant productivity and species composition are affected by moisture availability and grazing intensity. We examined warm- and cool-season grass productivity and relative distribution on grazed and ungrazed sites, receiving either natural precipitation or precipitation plus limited supplemental irrigation. The amount of additional water varied depending on rainfall during the previous week and was intended to shorten the interval between precipitation events and provide a more uniform seasonal moisture distribution. Irrigation treatments were superimposed in 1997 and 1998 on paddocks that had not been grazed for about 55 years or continuously stocked during the growing season for 15 years. Cool-season grasses dominated the ungrazed plots, comprising about $90 \%$ of the total biomass. In the grazed plots, the proportion of $C_{3}$ grasses ranged from 30 to $81 \%$. The proportion of $\mathrm{C}_{3}$ grasses in the grazed treatment decreased from spring to fall and decreased with supplemental irrigation. Root biomass was greater and more concentrated near the soil surface in the grazed compared with the ungrazed plots. Irrigation had no effect on root biomass in the grazed plots while irrigation reduced total root biomass and root biomass in the top $5 \mathrm{~cm}$ of the soil profile in the ungrazed plots. Irrigation increased total aboveground biomass only at the August 1997 harvest. Aboveground biomass of warm-season grasses, however, increased under irrigation in the grazed plots in August and November 1997 and August 1998. These increases, however, were offset by a reduction in cool-season grasses in November 1997 and August 1998. Warm-season grasses were particularly responsive to the supplemental irrigation treatments and tended to increase under irrigation at the expense of cool-season grasses. Because of the increased proportion of warm-season grasses, grazed plots were more responsive to irrigation than ungrazed plots.

Key Words: mixed-grass prairie, species composition, water stress

In mixed-grass prairies, the distribution of precipitation can be as important as the quantity received in determining forage productivity and the relative composition of species in the stand. The

The authors wish to thank Matt Mortenson for his help in collecting the soil cores and Cathy Krumwiede for obtaining the soil moisture data.

Manuscript accepted 28 Nov. 01.

\section{Resumen}

La productividad de las plantas del pastizal y la composición de especies son afectadas por la disponibilidad de humedad y la intensidad de apacentamiento. Examinamos la productividad de zacates de estación fría y caliente y su distribución relativa en sitios apacentados y no apacentados, recibiendo precipitación natural o precipitación mas irrigación suplementaria limitada. La cantidad de agua adicional varió dependiendo de la precipitación ocurrida durante la semana previa y se intento acortar el intervalo entre los eventos de precipitación para proveer una distribución estacional de la humedad más uniforme. Los tratamientos de irrigación fueron impuestos en 1997 y 1998 en potreros que no habían sido apacentados por aproximadamente 55 años o utilizados continuamente por 15 años durante la estación de crecimiento. Los zacates de estación fría dominaron en los potreros sin apacentamiento, comprendiendo aproximadamente el $90 \%$ de la biomasa total. En los potreros apacentados la proporción de zacates $C_{3}$ vario de 30 a $81 \%$. La proporción de zacates $C_{3}$ en los potreros apacentados disminuyó de primavera a otoño y con la irrigación suplementaria. La biomasa de raíz fue mayor y más concentrada cerca de la superficie del suelo en las parcelas apacentadas en comparación con las no apacentadas. La irrigación no tuvo efecto en la biomasa de raíz de los potreros apacentados mientras que en los potreros apacentados la irrigación redujo la biomasa total de raíz y la biomasa de raíz en los 5 primeros centímetros del perfil del suelo. La irrigación incremento la biomasa total aérea solo en la cosecha de agosto de 1997. Sin embargo, en los potreros apacentados, la irrigación aumento la biomasa aérea de los zacates de estación caliente durante agosto y noviembre de 1997 y agosto de 1998, pero este aumento fue anulado por una reducción de los zacates de estación fría en noviembre de 1997 y agosto de 1998. Los zacates de estación caliente respondieron a los tratamientos de irrigación suplementaria y tendieron a incrementarse bajo irrigación a expensas de los zacates de estación fría. Debido a la mayor proporción de zacates de estación caliente, las parcelas apacentadas respondieron mejor a la irrigación que los potreros sin apacentamiento.

majority of annual precipitation occurs during the growing season (May to September), primarily as irregularly spaced thunderstorms. Between these periodic rainfall events, severe moisture stress can develop (Chung and Trlica 1980). Warm-season grasses are particularly dependent on summer precipitation while most cool-season grass growth occurs early in the season and is more 
dependent on stored soil moisture (Hyder et al. 1976, Hart et al. 1993). The warmseason grass, blue grama (Bouteloua gracilis [H.B.K.] Lag. Ex Steud.), is particularly responsive to small summer rainstorms, and it has been proposed that the dominance of this grass in the Central and Southern Great Plains of the United States is related to its ability to utilize small volume rainfall events (Sala and Lauenroth 1982). Intensive grazing may reduce the negative effect of drought by reducing transpiring leaf area, thereby conserving soil moisture (Archer and Detling 1986, Day and Detling 1994). The effects of grazing intensity on plant responses to drought are species specific (Olson et al. 1985), suggesting that the interaction between drought and grazing could significantly affect botanical composition of rangelands.

Our objective was to determine the productivity and relative distribution of warm- and cool-season grasses on grazed and ungrazed sites that received either natural precipitation or precipitation plus limited supplemental irrigation. We hypothesized that additional moisture would favor production of warm-season grasses at the expense of cool-season grasses because of the greater ability of warm-season grasses to respond to summer precipitation. We also hypothesized that ungrazed plots would be more susceptible to drought than the grazed plots because of their greater leaf area, and thus, more responsive to supplemental irrigation.

\section{Materials and Methods}

The research was conducted at the High Plains Grassland Research Station near Cheyenne, Wyoming $\left(41^{\circ} 11^{\prime} \mathrm{N}\right.$ latitude, $104^{\circ} 53^{\prime} \mathrm{W}$ longitude) on a native mixedgrass rangeland. The climate is semi-arid with an annual frost-free period of 127 days and average annual precipitation of $384 \mathrm{~mm}$. Precipitation is lowest in January, increases to a peak in late-May or early-June, then declines throughout the rest of the year. This decline is interrupted by a brief rainy period from mid-July to early-August.

Treatment pastures were established in 1982. Prior to establishment of the pastures, the area had not been grazed by domestic livestock for at least 40 years. This study was superimposed on 2 of 7 grazing treatments that exist at the site. They were, 1) ungrazed exclosures, and 2) pastures with continuous season-long stocking at a rate of 0.56 steers/ha designed to remove $\approx 50 \%$ of annual production. Both sites were located on an Ascalon sandy loam soil (mixed mesic, aridic argiustoll). This is a deep, well drained soil on nearly level alluvial fans. Yearly forage production ranges from about 800 to $2,100 \mathrm{~kg} \mathrm{ha}^{-1}$.

In the spring of 1997 , two sub-sites dominated by grasses were selected within the grazed and ungrazed sites and 6 plots measuring $1.1 \times 1.9 \mathrm{~m}$ were staked out within each sub-site. Non-grass species comprised about $30 \%$ of the aboveground biomass and did not differ significantly between grazed and ungrazed sites. Subsites within the grazed site were fenced for the duration of the experiment to protect them from grazing and to allow measurement of plant biomass production. All further reference to the "grazed site", therefore, refers to its historical use and not to management practices during the course of the experiment. Three plots per sub-site received supplemental irrigation while 3 received only ambient rainfall. Supplemental irrigation was applied from earlyJune through late-September in 1997 and 1998. Irrigation applications were designed to ensure that plots received water at rates equal to at least $17.5 \mathrm{~mm}$ week $^{-1}$. This rate was equal to average weekly precipitation rates during May, which is the wettest month of the year. Irrigation applications were designed to even out water availability throughout the summer. Using a hand-held hose and sprinkler nozzle attached to a 300 liter tank, water was applied weekly based on precipitation received during the preceding week. If rainfall during the week exceeded $17.5 \mathrm{~mm}$ then no additional water was added. If rainfall was $<17.5 \mathrm{~mm}$ then sufficient water was applied to bring the total up to that amount.

Biomass was estimated in mid-May, early-August, and early-November in 1997 and 1998 by removing $10-\mathrm{cm}$ diameter soil cores to a depth of $30 \mathrm{~cm}$ from each plot. Standing aboveground vegetation was separated into warm-season grasses, cool-season grasses and non-grass species. Blue grama and western wheatgrass [Pascopyrum smithii [Rydb.] A. Love (formerly Agropyron smithii)] were the predominant warm- and cool-season grasses, respectively, at both sites. Root, crown and litter fractions were collected but not identified by functional group. Roots were separated into 0 to 5,5 to 15 , and 15 to $30 \mathrm{~cm}$ depths. Roots were ashed to correct for any soil contamination of the washed root samples and root data are presented on an ash-free dry matter basis.
Gravimetric soil moisture content was determined from separate cores collected at the same time and adjacent to those used for biomass determinations.

The grazed plots were mowed after the August sampling in 1997 to simulate the grazing that would have occurred if the plots had not been fenced. Because biomass removed by mowing would have been present at the November sampling if it had not been removed, it was added to plant material collected at that time. Analysis of variance tests were conducted with years and grazing treatments as fixed and water applications as random effects. Fisher's protected least significant difference tests were used for means comparisons.

\section{Results}

Total precipitation in 1997 was 579 mm, exceeding the average annual precipitation of $388 \mathrm{~mm}$ by nearly $50 \%$. Total precipitation in 1998 , however, was $315 \mathrm{~mm}$, or $81 \%$ of normal. Summer precipitation patterns were similar to annual amounts with the summer of 1997 (1 June to 30 September) being the $3^{\text {rd }}$ wettest in the 82 years that records are available, while the summer of 1998 was the $7^{\text {th }}$ driest. Despite the high rainfall in 1997 , no rain fell during a 1 month period from late-June to late-July (Fig. 1). Another relatively dry period occurred between mid-August and mid-September. These 2 dry periods were separated by a month which received approximately 3-times the normal rainfall. Ten irrigations were applied in 1997, supplying $145 \mathrm{~mm}$ of supplemental water. The summer of 1998 was dry throughout the late-June to September period (Fig. 1), although April and May precipitation was slightly above normal (data not shown). In 1998, plots received $221 \mathrm{~mm}$ of additional moisture in 16 irrigations.

Both irrigation treatment and previous grazing management had little effect of soil moisture in 1997 (Fig. 2). Because of the abundant rainfall just before the August harvest and again in late September (Fig. 1), soil moisture in the cores was near field capacity in all plots when the last 2 harvests were taken in 1997. Because soil moisture measurements were only collected at the time of harvest, we have no data on how irrigation treatments might have affected soil moisture prior to the late July and early August rains. Significant soil moisture deficits developed during the summer of 1998 with the ungrazed plots being wetter than the grazed plots (Fig. 2). Irrigation treat- 


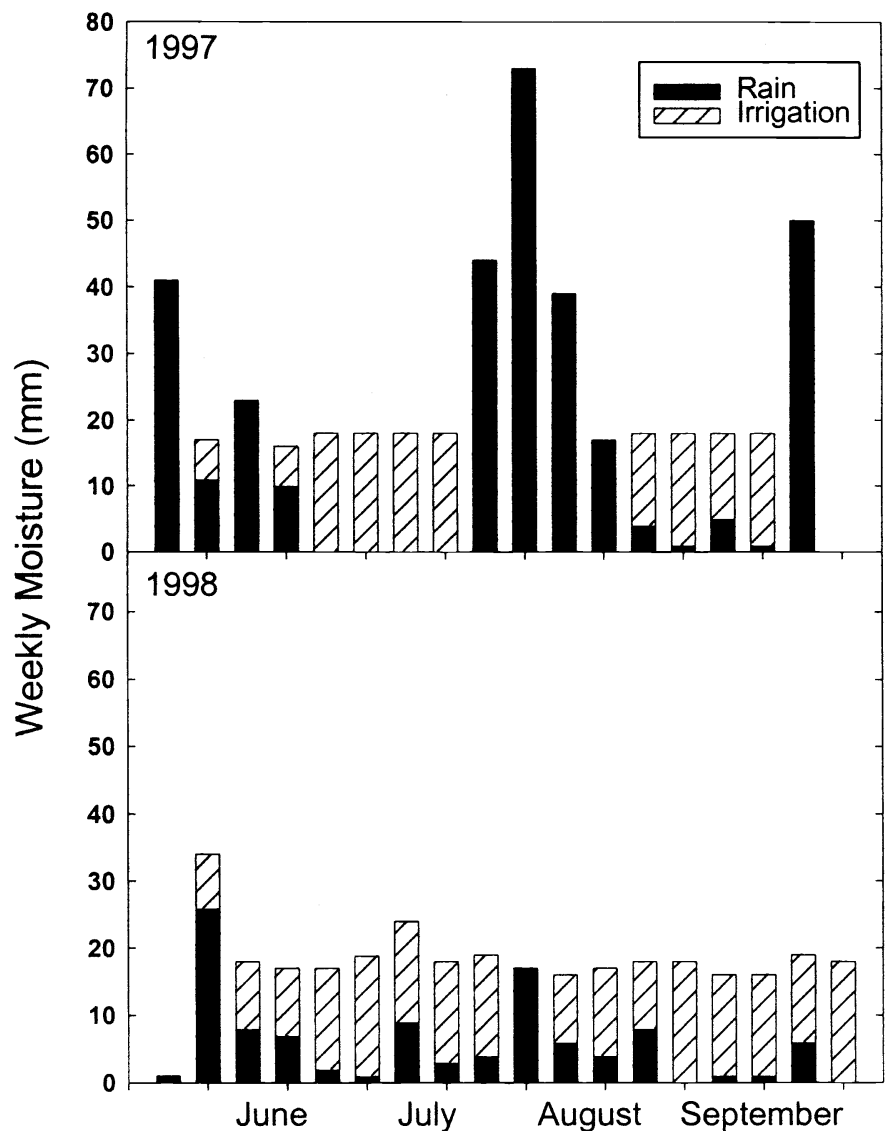

Fig. 1. Weekly precipitation and irrigation applications during the summers of 1997 and 1998. When precipitation for the proceeding week was less than $17.5 \mathrm{~mm}$ supplemental irrigation was applied to bring the weekly total to $17.5 \mathrm{~mm}$.

ments significantly $(\mathrm{P}<0.01)$ increased soil moisture content at the August harvest in both the grazed and ungrazed plots. Soil moisture was again near field capacity in all plots when harvests were taken in November 1998.

Supplemental irrigation had no significant effect on root biomass in the grazed plots (Table 1). In the ungrazed treatment, irrigation reduced total root biomass and the biomass of roots in the top $5 \mathrm{~cm}$ of the soil profile. Grazed plots had significantly larger root systems than the ungrazed plots and a greater proportion of the roots were located near the soil surface in the grazed plots. Seventy nine percent of the roots in the grazed treatment were in the top $5 \mathrm{~cm}$ compared with $69 \%$ in the ungrazed plots. Irrigation treatment had no detectable effect on root distribution within the soil profile.

Supplemental irrigation increased aboveground biomass $\left(\mathrm{C}_{3}\right.$ plus $\mathrm{C}_{4}$ grasses $)$ at the August sampling in 1997 but not in 1998 (Fig. 3). There was no difference in aboveground biomass between the August 1997 and August 1998 harvests in the non-irrigated treatment. However,

was significantly lower 1997 , and significantly lower than the August 1998 harvest, suggesting that senescence and transfer of leaves to the litter pool was proceeding faster than leaf growth. Adding supplemental water did not enhance total late-summer biomass production compared with the non-irrigated plots.

The ungrazed site was dominated by $\mathrm{C}_{3}$ grasses (Fig. 4 and Fig. 5) in both years and at all 3 harvests within each year. Irrigation increased the biomass of $\mathrm{C}_{3}$ grasses in the ungrazed plots at the August
1997 harvest, but had no effect on $\mathrm{C}_{3}$ grasses at any other harvest. Irrigation had no effect on $\mathrm{C}_{3}$ biomass at any harvest in the grazed plots. However, irrigation increased biomass of $\mathrm{C}_{4}$ grasses in the grazed plots at the August and November 1997 harvests $(P<0.05)$. A similar trend of increased biomass production with irrigation was observed for $\mathrm{C}_{4}$ grasses in the grazed plots in August $1998(\mathrm{P}<0.10)$. Increased production of $\mathrm{C}_{4}$ grasses occurred in both the irrigated and non-irrigated grazed plots following mid-summer rains in 1997 . $C_{3}$ grasses did not respond to the above normal rainfall in 1997 in either grazing treatment.

The ungrazed sites had a much greater proportion of $\mathrm{C}_{3}$ grasses than the grazed sites. When all harvests were combined, $\mathrm{C}_{3}$ species accounted for $92 \%$ of all grasses in the ungrazed plots (Fig. 5). Irrigation caused a decrease in the proportion of $\mathrm{C}_{3}$ grasses in the grazed plots. When all harvests were combined at the grazed site, the percentage of $\mathrm{C}_{3}$ grasses decreased from $63 \%$ in the non-irrigated to $52 \%$ in the irrigated treatment $(\mathrm{P}<0.05)$. Averaged across years, the percentage of $\mathrm{C}_{3}$ grasses at the grazed site decreased with successive harvests, falling from $66 \%$ in May to $48 \%$ in November $(\mathrm{P}<0.01)$. This decrease was much more pronounced in 1997 when midsummer rainfall led to an increase in latesummer $\mathrm{C}_{4}$ grass production.

\section{Discussion}

We hypothesized that supplemental irrigation would favor the production of warm-season grasses at the expense of cool-season species because of the greater ability of warm-season grasses to respond to summer precipitation. We also hypothesized that ungrazed plots would be more susceptible to drought than the grazed plots because of their greater leaf area, and thus, would be more responsive to supplemental irrigation.

Our data supported the hypothesis that

Table 1. Root biomass response to irrigation and previous grazing regime at the High Plains Grassland Research Station near Cheyenne, Wyo. Data are averaged across harvests and years with the exception of the May 1998 data which are missing. Data are expressed per $\mathrm{m}^{2}$ of soil surface area to facilitate comparisons with aboveground biomass and are \pm 1 Standard Error.

\begin{tabular}{lcccc}
\hline \hline & \multicolumn{4}{c}{ Soil Depth } \\
Treatment & $0-5 \mathrm{~cm}$ & $5-15 \mathrm{~cm}$ & $15-30 \mathrm{~cm}$ & Total Roots \\
\hline & $-1037 \pm 87$ & $171 \pm 14$ & $82 \pm 9$ & $1296 \pm 88$ \\
Grazed/non-irrigated & $1035 \pm 101$ & $188 \pm 23$ & $90 \pm 13$ & $1312 \pm 95$ \\
Grazed/irrigated & $652 \pm 48$ & $146 \pm 20$ & $122 \pm 22$ & $921 \pm 53$ \\
Non-grazed/non-irrigated & $551 \pm 26$ & $162 \pm 22$ & $104 \pm 16$ & $816 \pm 35$ \\
Non-grazed/irrigated & & & &
\end{tabular}




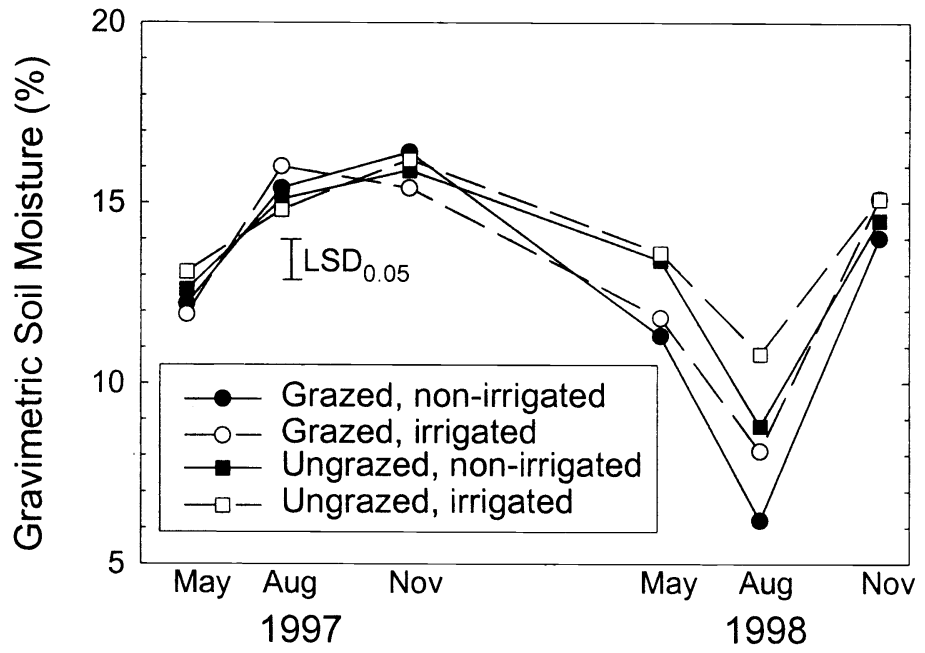

Fig. 2. Soil moisture content under plots that received only natural precipitation or that received weekly supplemental irrigation applications when needed during the summer to bring the weekly total to at least $17.5 \mathrm{~mm}$.

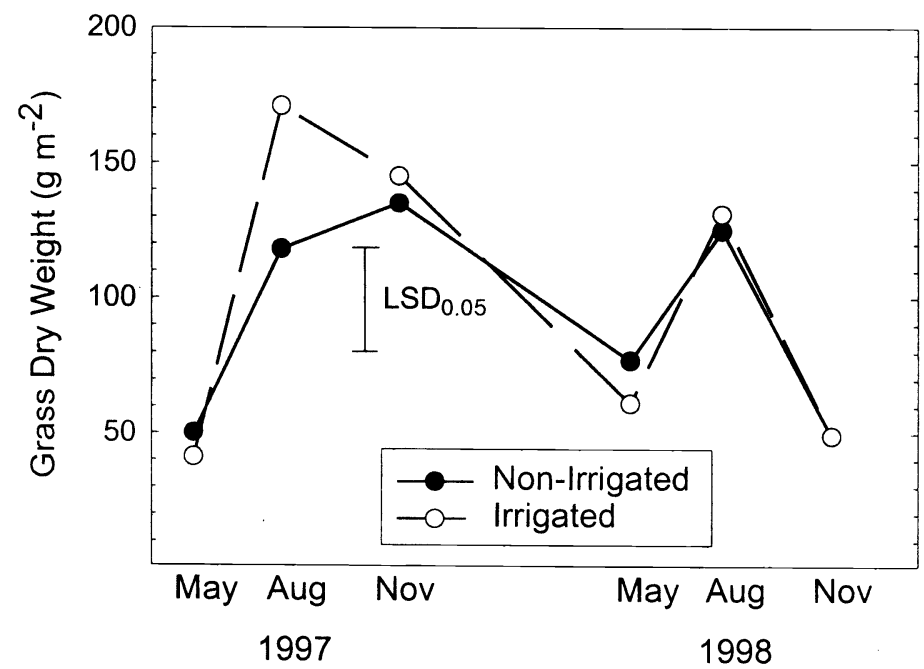

Fig. 3. Effect of irrigation on total grass production $\left(C_{3}\right.$ plus $\left.C_{4}\right)$ at mixed-grass prairie site near Cheyenne, Wyo. Data are combined across grazing treatments which showed no significant difference in total grass production.

$\mathrm{C}_{4}$ grasses are more responsive than $\mathrm{C}_{3}$ grasses to small precipitation events. Supplemental irrigation reduced the proportion of $\mathrm{C}_{3}$ grasses in the grazed plots in 1997 and 1998 and in the ungrazed plots in 1998 (Fig. 5). In addition, when data were averaged across years, grazing treatments, and harvests, $\mathrm{C}_{4}$ biomass increased under irrigation $(\mathrm{P}=0.02)$ while $\mathrm{C}_{3}$ biomass was unaffected. Chung and Trilca (1980) found that blue grama sods were capable of rapid recovery upon the relief of soil water stress to $-1.5 \mathrm{MPa}$ and suggested that blue grama was adapted to habitats where periods of extreme drought alternate with periods of abundant water. Sala and Lauenroth (1982) reported that leaf water potential and leaf conductance to water in blue grama increased within 12 hours following a small $(5 \mathrm{~mm})$ precipitation event, and that improved leaf water relations lasted for up to 2 days. This rapid response to rainfall would allow blue grama to be highly competitive under fluc-

Table 2. Mean daily air temperature and total monthly evaporative demand during the growing season at the High Plains Grassland Research Station near Cheyenne, Wyo.

\begin{tabular}{|c|c|c|c|c|c|c|}
\hline & May & June & July & August & September & October \\
\hline & & & -Air T & ature $\left({ }^{\circ} \mathrm{C}\right.$ & & . \\
\hline 1997 & 9.7 & 15.5 & 18.1 & 16.9 & 15.5 & 7.5 \\
\hline 1998 & 10.6 & 12.3 & 19.6 & 18.4 & 16.1 & 7.7 \\
\hline \multirow[t]{2}{*}{82 yr. Average } & 10.7 & 16.2 & 20.1 & 19.2 & 14.3 & 8.2 \\
\hline & & & $-P a n$ & ation (m & & \\
\hline 1997 & 90 & 96 & 91 & 47 & 71 & 78 \\
\hline 1998 & 71 & 54 & 195 & 133 & 150 & 133 \\
\hline
\end{tabular}




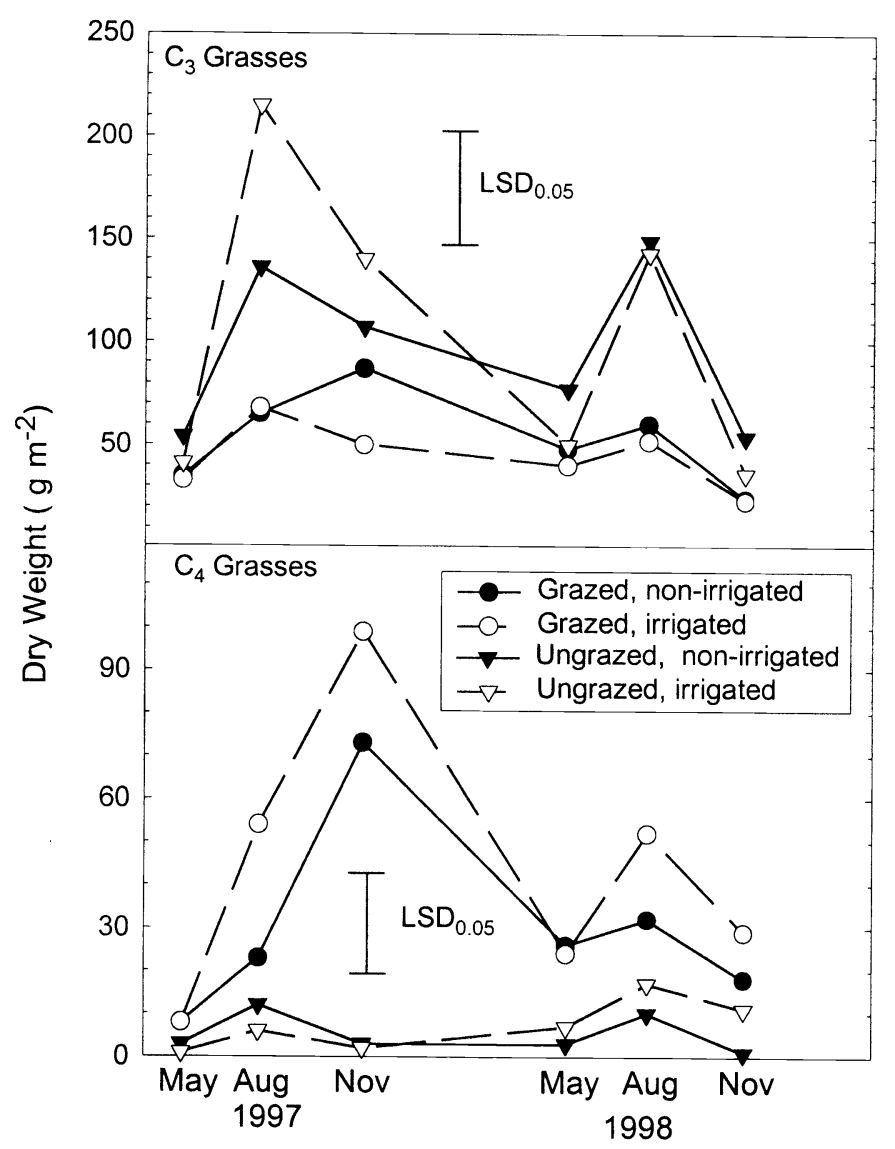

Fig. 4. Effect of irrigation on $\mathrm{C}_{3}$ and $\mathrm{C}_{4}$ grass production on sites that had not been grazed for about 55 years (ungrazed) or had experienced 15 years of continuous grazing (grazed).

vigorous root system and high carbohydrate reserve levels after defoliation (Buwai and Trlica 1977). Because defoliation is usually less damaging to blue grama than to western wheatgrass, blue grama often increases as stocking rate increases while western wheatgrass decreases (Hart et al. 1993). The lower proportion of $\mathrm{C}_{3}$ grasses that we observed in the grazed plots was consistent with these observations. In the ungrazed plots, species composition remained more constant across years, harvests and irrigation treatments than in the grazed plots, suggesting that the grass community had become a relatively stable, $\mathrm{C}_{3}$ dominated system in the 50 plus years that grazing had been excluded from those sites. Fifteen years of grazing, however, produced a more dynamic system with species composition being affected by irrigation treatment, harvest, and year by harvest interactions.

Even though yearly precipitation was $84 \%$ greater, and June to September precipitation $178 \%$ greater in 1997 than 1998 , May and August biomass in non-irrigated plots were similar in 1997 and 1998 (Fig. non-irrigated plots greater in 1997 than in 1998. Others have found that forage yields are not necessarily related to yearly moising (GR). ture availability (Wilms et al. 1993, Heitschmidt et al. 1999). To understand the apparent discrepancies between forage production and precipitation, seasonal trends in the growth of the different plant functional groups must be compared with seasonal changes in rainfall and evaporative demand. Cool-season grasses, in general, and western wheatgrass, in particular, grow primarily during the spring and early-summer. In an earlier study at the same site, western wheatgrass produced little growth in either grazed or ungrazed plots after mid-July (Hart et al. 1993). Blue grama, on the other hand, continued to grow through August (Hart et al. 1993) and depended on summer precipitation to prevent tiller death and thinning of the stand (Hyder et al. 1976).

The early summer of 1998 was characterized by adequate precipitation in April and May, lower than average temperatures in May and June and a concomitant reduction in evaporative demand compared with the same period in 1997 (Table 2). Under these conditions, both $\mathrm{C}_{3}$ and $\mathrm{C}_{4}$ biomass production in 1998 were equal to production in 1997. In a Canadian study involving many of the same species found on our sites, high precipitation and low pan evaporation during the spring of an otherwise dry year resulted in greater herbage production than was observed in years with average precipitation but with less favorable seasonal distribution patterns (Willms et al. 1993). The severe drought that developed in July, August, and September 1998 severely inhibited late-summer $\mathrm{C}_{4}$ production compared with 1997 when abundant mid-summer rainfall produced a flush of late-summer growth (Fig. 4).

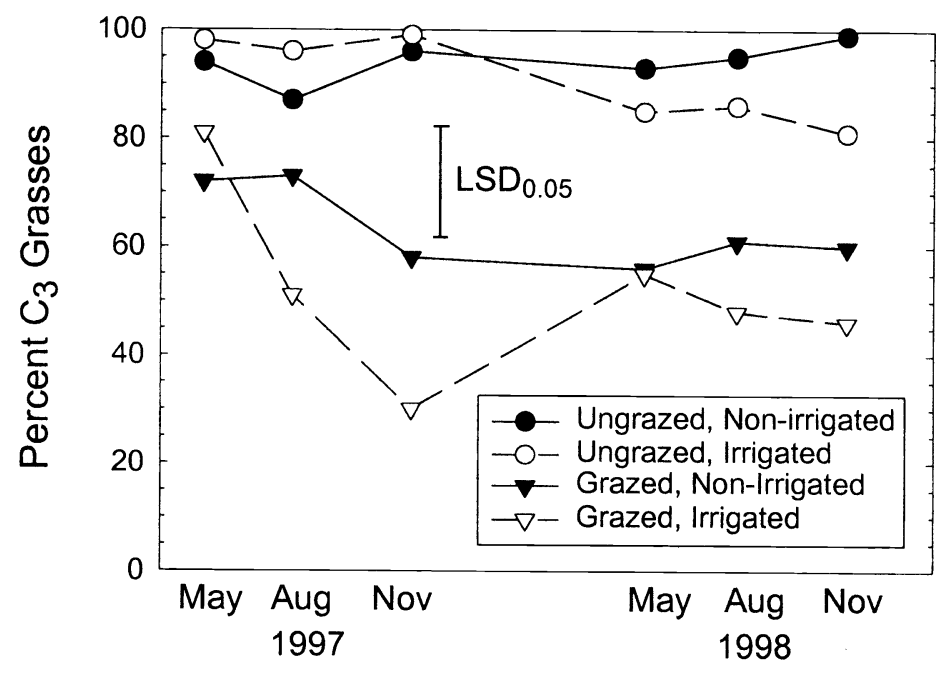

Fig. 5. Effect of irrigation on the proportion of $\mathrm{C}_{3}$ compared with $\mathrm{C}_{4}$ grasses on sites that had not been grazed for about 55 years (UG) or had experienced 15 years of continuous graz- 
Our data did not support the second hypothesis that ungrazed plots would be more susceptible to drought because of their increased leaf area and greater evapotranspiration. During the greatest period of drought in August 1998, soil water content was actually greater in the ungrazed plots (Fig. 2). The taller plants in the ungrazed plots could have shaded the soil surface, reducing evaporation. In August, $61 \%$ of the cool-season grass standing biomass was living compared with $75 \%$ of the warm-season grass biomass. The lower proportion of green living tissue could have also resulted in reduced transpiration in the $\mathrm{C}_{3}$ dominated ungrazed plots. LeCain et al. (2000) also found that soil water content was greater in ungrazed compared with grazed plots and suggested that the greater accumulation of litter and standing dead in the ungrazed plots acted as a mulch, conserving moisture stored during the winter. The ungrazed plots were also less responsive to supplemental irrigation because they contained only a small proportion of the $\mathrm{C}_{4}$ grasses that were most responsive to additional summer moisture availability.

In conclusion, supplemental irrigation increased warm-season grass production relative to the production of cool-season grasses. The shift toward warm-season grasses probably occurred because of the larger, more shallow root systems of the warm-season grasses which improved moisture acquisition following irrigation treatments. Contrary to our original hypothesis, there was no indication that ungrazed plots were more sensitive than grazed plots to drought stress, or more responsive to supplemental irrigation. This was probably because of the mulching effect of the litter and standing dead and because of the dominance of deep-rooted cool-season species in the ungrazed plots.

\section{Literature Cited}

Archer, S. and J.K. Detling. 1986. Evaluation of potential herbivore mediation of plant water status in a North American mixedgrass prairie. Oikos 47:287-291.

Bartos, D.L. and P.L. Sims. 1974. Root dynamics of a shortgrass ecosystem. J. Range Manage. 27:33-36.

Biondini, M.E., B.D. Patton, and P.E. Nyren. 1998. Grazing intensity and ecosystem processes in a northern mixed-grass prairie, USA. Ecol. Appl. 8:469-479.

Buwai M. and M.J. Trlica. 1977. Defoliation effects on root weights and total nonstructural carbohydrates of blue grama and western wheatgrass. Crop Sci. 17:15-17.

Chung, H.H. and M.J. Trlica. 1980. ${ }^{14} \mathrm{C}$ distribution and utilization on blue grama as affected by temperature, water potential and defoliation regimes. Oecologia 47:190-195.

Day T.A. and J.K. Detling. 1994. Water relations of Agropyron smithii and Bouteloua gracilis and community evapotranspiration following long-term grazing by prairie dogs. Amer. Midl. Nat. 132:381-392.

Dormaar, J.F., B.W. Adams, and W.W. Willms. 1997. Impacts of rotational grazing on mixed prairie soils and vegetation. J. Range Manage. 50:647-651.

Hart, R.H., S. Clapp, and P.S. Test. 1993. Grazing strategies, stocking rates, and frequency and intensity of grazing on western wheatgrass and blue grama. J. Range Manage. 46:122-126.

Heitschmidt, R.K., M.R. Haferkamp, M.G. Karl, and A.L. Hild. 1999. Drought and grazing: I. Effects on quantity of forage produced. J. Range Manage. 52:440-446.

Hyder, D.N., W.R. Houston, and J.B. Burwell. 1976. Drought resistance of blue grama as affected by atrazine and $\mathrm{N}$ fertilizer. J. Range Manage. 29:214-216.

LeCain, D.R., J.A. Morgan, G.E. Schuman, J.D. Reeder, and R.H. Hart. 2000. Carbon exchange rates in grazed and ungrazed pastures of Wyoming. J. Range Manage. 53:199-206.
McNaughton, S.J. 1983. Serengeti grassland ecology: the role of composite environmental factors and contingency in community organization. Ecol. Monogr. 53:291-320.

McNaughton, S.J. 1984. Grazing lawns: animals in herds, plant form, and coevolution. Amer. Natur. 124:863-886.

Milchunas D.G. and W.K. Lauenroth. 1989. Three-dimensional distribution of plant biomass in relation to grazing and topography in the shortgrass steppe. Oikos 55:82-86.

Milchunas D.G. and W.K. Lauenroth. 1993. Quantitative effects of grazing on vegetation and soils over a global range of environments. Ecol. Monogr. 63:327-366.

Olson, K.C., R.S. White, and B.W. Sindelar. 1985. Response of vegetation of the Northern Great Plains to precipitation amount and grazing intensity. J. Range Manage. 38:357-361.

Sala, O.E. and W.K. Lauenroth. 1982. Small rainfall events: an ecological role in semiarid regions. Oecologia 53:301-304.

Schuman, G.E., J.D. Reeder, J.T. Manley, R.H. Hart, and W.A. Manley. 1999. Impact of grazing management on the carbon and nitrogen balance of a mixed-grass rangeland. Ecol. Appl. 9:65-71.

Stohlgren, T.J., L.D. Schell, and B.V. Heuvel. 1999. How grazing and soil quality affect native and exotic plant diversity in Rocky Mountain grasslands. Ecol. Appl. 9:45-64.

Willms, W.D., S.M. McGinn, and J.F. Dormaar. 1993. Influence of litter on herbage production in the mixed prairie. J. Range Manage. 46:320-324. 